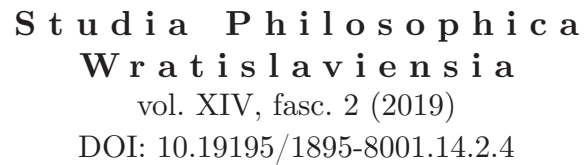

KRZYSZTOF SĘKOWSKI

ORCID: 0000-0001-6547-9997

Uniwersytet Warszawski

\title{
Analiza empirycznych argumentów na rzecz tezy o zróżnicowaniu kulturowym intuicji epistemicznych*
}

\section{An analysis of empirical arguments for the thesis on cultural diversity of epistemic intuitions}

Abstract: The founding text for the new current in modern philosophy- experimental philosophy - can be seen in Jonathan Weinberg, Shaun Nichols and Stephen Stich's "Normativity and Epistemic Intuitions" (2001). The authors describe in this article a study to prove cross-cultural differences in epistemic intuitions. On the basis of their results, they argue that since epistemic intuitions seem to serve a crucial role in the use of thought experiments, contemporary philosophical methodology is highly unjustified.

That study has brought about at least three replication attempts (Seyedsayamdost 2015; Kim, Yuan 2015; Nagel, San Juan, Mar 2013). None of them confirmed the original results.

The aim of this article is to critically analyze in detail Weinberg, Nichols and Stich's methodology and the three replications mentioned. Regarding the results of my analysis, I will try to examine what conclusions can be drawn with regard to the outcomes of analized studies. In particular I will refer to far-reaching conclusions about the universality of epistemic intuitions or universality of folk epistemology, which are sometimes - hastily, as I will argue - extrapolated from the results of such kind of studies (e.g., Kim, Yuan 2015; Kim Yuan 2016).

Keywords: experimental philosophy, epistemic intuitions, intercultural differences, philosophical methodology, colloquial epistemology

\footnotetext{
* Praca naukowa finansowana ze środków budżetowych na naukę w latach 2018-2022, jako projekt badawczy w ramach programu „Diamentowy Grant” (nr projektu: DI2017 001347).
}

Studia Philosophica Wratislaviensia 14, 2019 z. 2

(C) for this edition by CNS 


\section{Wprowadzenie - filozofia eksperymentalna}

Filozofia eksperymentalna jest nowym — powstałym na początku XXI wieku - nurtem w filozofii analitycznej. Ze względu na przyjmowanie zupełnie odmiennych od tradycyjnej filozofii założeń metodologicznych budzi skrajne emocje, a jej uprawomocnienie jest żywo dyskutowanym problemem na gruncie metafilozofii. Wielu filozofów stawia poważne zarzuty pod adresem metod filozofii eksperymentalnej — jej roszczeń i wniosków, które filozofowie eksperymentalni wysnuwaja z własnych badań ${ }^{1}$. Artykuł ten poświęcony jest analizie metodologicznej pionierskiego dla filozofii eksperymentalnej i niezwykle wpływowego badania Weinberga, Nicholsa i Sticha opisanego w artykule Normativity and Epistemic Intuitions ${ }^{2}$, a także analizie trzech prób jego powtórzenia ${ }^{3}$.

Przed omówieniem zarówno wymienionych badań, jak i wspomnianych kontrowersji związanych z filozofią eksperymentalną warto przedstawić pokrótce trzy odłamy, które można wyróżnić w jej ramach — analizę eksperymentalną, eksperymentalny deskrypcjonizm oraz eksperymentalny restrykcjonizm ${ }^{4}$. Pozwoli to nakreślić główne założenia, metody i cele filozofii eksperymentalnej, nie pomijając jednocześnie jej wewnętrznego zróżnicowania.

Badacze uprawiający analizę eksperymentalną stawiają sobie za cel ustalenie zgodności teorii lub znaczeń pojęć będących efektem pracy filozofów-teoretyków z powszechnymi intuicjami. Badania te posługują się najczęściej metodą sondażową, rzadziej ściśle eksperymentalną. Do tej grupy należą między innymi wczesne badania Knobe'a dotyczacce intencjonalności ${ }^{5}$ czy Nahmiasa i współpracowników, w których przedmiotem zainteresowania były intuicje na temat wolnej woli ${ }^{6}$.

Eksperymentalny deskrypcjonizm to nurt poszukujacy społecznego i poznawczego wyjaśnienia wyników uzyskanych w badaniach eksperymentalnych. Odłam ten ma najbardziej interdyscyplinarny charakter. Coraz częściej korzysta z osią-

${ }^{1}$ Por. np. K. Ludwig, The epistemology of thought experiments: First person versus third person approaches, „Midwest Studies in Philosophy” 31 [1] (2007), s. 128-159; A. Kauppinen, The rise and fall of experimental philosophy, „Philosophical explorations” 10 [2] (2007), s. 95-118; M. Deutsch, Intuitions, counter-examples, and experimental philosophy, „Review of Philosophy and Psychology" 1 [3] (2010), s. 447-460; M. Deutsch, The myth of the intuitive: Experimental philosophy and philosophical method, London 2015; H. Cappelen, Philosophy without intuitions, Oxford 2012; H. Cappelen, X-Phi without Intuitions, [w:] Intuitions, A. Booth, D. Rowbottom (eds.), Oxford 2014, s. 269-286, T. Williamson, Philosophical Criticisms of Experimental Philosophy, [w:] A Companion to Experimental Philosophy, J. Sytsma, W. Buckwalter (eds.), New York 2016.

2 J.M. Weinberg, S. Nichols, S. Stich, Normativity and epistemic intuitions, „Philosophical Topics” 29 [1-2] (2001), s. 429-460.

${ }^{3}$ H. Seyedsayamdost, On normativity and epistemic intuitions: Failure of replication, „Episteme” 12 [1] (2015), s. 95-116; J. Nagel, V. San Juan, R. A. Mar, Lay denial of knowledge for justified true beliefs, „Cognition” 129 [3] (2013), s. 652-661; M. Kim, Y. Yuan, No cross-cultural differences in the Gettier car case intuition: A replication study of Weinberg et al. 2001, „Episteme” 12 [3] (2015), s. 355-361.

${ }^{4}$ Por. T. Nadelhoffer, E. Nahmias, The past and future of experimental philosophy, „Philosophical Explorations" 10 [2] (2007), s. 123-149.

${ }^{5} \mathrm{~J}$. Knobe, Intentional action in folk psychology: An experimental investigation, „Philosophical Psychology" 16 [2] (2005), s. 309-325.

${ }^{6}$ E. Nahmias, S.G. Morris, T. Nadelhoffer, J. Turner, Is Incompatibilism Intuitive?, „Philosophy and Phenomenological Research", 73 [1] (2006), s. 28-53. 
gnięć i metod innych nauk, na przykład neuropsychologii jak w badaniach Greene'a dotyczących sądów moralnych ${ }^{7}$. Eksperymentalny deskrypcjonizm zwykle korzysta jednak z metody scenariuszowej. Po zapoznaniu się ze scenariuszem, osoby badane pytane są o ocenę stanów lub działań bohatera, co pozwala badaczom określić intuicje osób badanych. Ostatecznym celem deskrypcjonistów jest zaś wyjaśnienie, z czego wynikają takie, a nie inne intuicje. Cel ten realizuje się w dwóch krokach. Najpierw deskrypcjoniści starają się ustalić psychologiczne i społeczne czynniki wpływające na intuicje badanych. Po osiągnięciu tego na horyzoncie pojawia się kolejne wyzwanie ostateczny cel, jakim jest stworzenie bardziej abstrakcyjnej i ogólnej teorii tłumaczącej mechanizm odpowiedzialny za owe intuicje ${ }^{8}$.

Eksperymentalny restrykcjonizm jest odłamem filozofii eksperymentalnej, którego celem jest ocena metodologiczna badań filozoficznych. Korzysta on z metod używanych przez oba nurty. Jego celem jest wykazanie bezużyteczności metody eksperymentów myślowych w filozofii. Argumentem na rzecz tej tezy mają być udowodnione $\mathrm{w}$ badaniach eksperymentalnych różnice w intuicjach, które zdaniem filozofów eksperymentalnych, pełnią rolę uzasadniającą w argumentacjach opartych na eksperymentach myślowych. Pionierskim badaniem zarówno dla tego nurtu, jak i dla całej filozofii eksperymentalnej były eksperymenty Jonathana Weinberga, Shauna Nicholsa i Stephena Sticha ${ }^{9}$, których analiza jest głównym przedmiotem ninejszego artykułu.

\section{Kontrowersje związane z filozofią eksperymentalną}

Znaczenie wyników badań prowadzonych w nurcie analizy eksperymentalnej jest przez wielu filozofów podważane między innymi ze względu na ich niedokładność metodologiczną. Często, aby podważyć wyniki analizy eksperymentalnej, które są nieprzystające do osiągnięć tradycyjnej analizy pojęciowej, krytycy badań filozofii eksperymentalnej tworzą różnego rodzaju teorie błędu (ang. error theories). Za ich pomocą starają się wyjaśnić wyniki otrzymane w badaniach eksperymentalnych niewłaściwym zrozumieniem problemu przez badanych lub przyjmowaniem przez nich dodatkowych założeń ${ }^{10}$. Dodatkowo, jak zaznaczają Knobe i Nichols ${ }^{11}$, nawet w przypadkach, w których nie można podważyć metodologicznej części badań wskazujących na niezgodność powszechnych intuicji z jakąś teorią filozoficzną, niezgodność ta nie musi być zmartwieniem filozofów. Celem tradycyjnych analiz filozoficznych nie jest stworzenie pojęć i teorii, które byłyby po prostu „popularne”. Pomimo braku zgodności teorii filozoficznych z intuicjami większości ludzi moga one być wartościowe z innych powodów, na przykład ze względu na logiczną niesprzeczność. Wynikiem takiego podejścia są formułowane przeciw filo-

7 J. Greene, J. Haidt, How (and where) does moral judgment work?, „Trends in Cognitive Science” 6 [12] (2002), s. 517-523.

8 Por. J. Knobe, S. Nichols, An Experimental Philosophy Manifesto, [w:] Experimental Philosophy,

J. Knobe, S. Nichols (eds.), Oxford 2008, s. 3-14.

${ }^{9}$ J.M. Weinberg, S. Nichols, S. Stich, Normativity..., s. 429-460.

${ }^{10}$ Por. J. Alexander, Experimental Philosophy. An Introduction, Cambridge 2012, s. 32-33.

11 Por. J. Knobe, S. Nichols, An Experimental..., s. 6. 
zofii eksperymentalnej tak zwane argumenty z eksperta, zarzucające filozoficzną irrelewantność wyników eksperymentów przeprowadzanych na laikach.

Badania deskrypcjonizmu eksperymentalnego są krytykowane z dwóch pozycji. Pierwsza wskazuje na niską wartość metodologiczną tych badań. Między innymi Robert Woolfolk ${ }^{12}$ wskazuje, że filozofia eksperymentalna, korzystając z metod nauk społecznych, nie spełnia jej standardów. Uwidacznia się to w niezmiernie rzadkim reprezentatywnym doborze próby osób badanych, niskiej trafności i rzetelności badań filozofii eksperymentalnej oraz niewielkiej przejrzystości tych badań. Zarzuty drugiego rodzaju dotyczą tego, czy deskrypcjonizm eksperymentalny może zostać w ogóle uznany za filozofię. Rzeczywiście warto zauważyć, że deskrypcjonizm eksperymentalny nie jest nurtem o normatywnych aspiracjach. Niektórzy filozofowie eksperymentalni jasno przyznają, że badania z tego nurtu powinny być zaliczone do kognitywistyki ${ }^{13}$. Jednak zdaniem na przykład Timothy'ego Williamsona $^{14}$ filozofia eksperymentalna w ogólności jest co najwyżej imitacją psychologii, a jej cele i metody nie są w ogóle spójne z tymi przyjętymi w filozofii. Tego typu argumenty są wyjątkowo interesującym zjawiskiem w środowisku filozoficznym. Z perspektywy metafilozofii wyznaczenie określonej linii demarkacyjnej między filozofią a niefilozofią jest jednym z nierozstrzygniętych i żywo dyskutowanych problemów, a co za tym idzie, zarówno uznanie, jak i nieuznanie filozofii eksperymentalnej za filozofię jest pewnym stanowiskiem filozoficznym, które wymaga uzasadnienia. Mimo to po stronie przeciwników filozofii eksperymentalnej — takich jak Timothy Williamson — problem ten wydaje się na wstępie rozwiązany. Podobnie jednak zachowują się także jej niektórzy obrońcy — jak Joshua Knobe czy Shaun Nichols ${ }^{15}$, którzy, odnosząc się do omawianych zarzutów, argumentują, stwierdzając, że to, że filozofia eksperymentalna jest filozofią, jest dla nich tak oczywiste, że nie wymaga dodatkowej argumentacji. Konsekwencją takiego stanu rzeczy jest pewnego rodzaju ostracyzm ze strony niektórych przeciwników filozofii eksperymentalnej oraz zamknięcie na krytykę założeń filozofii eksperymentalnej ze strony jej obrońców. Obie strony natomiast, przyjmując tego typu stanowisko, wprowadzaja szkodliwy marazm intelektualny na polu metafilozofii. Faktem jest bowiem, że filozofia eksperymentalna jest żywym kierunkiem we współczesnej filozofii analitycznej. Także w polskim środowisku badania w tym duchu prowadzone są lub były na Uniwersytecie Warszawskim, Katolickim Uniwersytecie Lubelskim czy Uniwersytecie Wrocławskim. W Europie i Stanach Zjednoczonych powstaje wiele grup badających potoczne intuicje i wysnuwających ze swoich wyników filozoficzne wnioski. Krytyka filozofii eksperymentalnej nie powinna więc ograniczyć się jedynie do stwierdzenia, że nie jest ona filozofią. Jest to teza filozoficzna i jako

12 Por. R.L. Woolfolk, Experimental Philosophy: A Methodological Critique, „Metaphilosophy” 44 [1-2] (2013), s. 79-87.

${ }_{13}$ Por. J. Knobe, Experimental philosophy is cognitive science, [w:] A companion to experimental philosophy, J. Sytsma, W Buckwalter (eds.), New York 2016, s. 37-52.

14 Por. T. Williamson, Philosophy vs. Imitation Psychology, ,The New York Times” 2010, https:// www.nytimes.com/roomfordebate/2010/08/19/x-phis-new-take-on-old-problems/philosophy-vs-imitation-psychology (dostęp: 2.03.2019).

${ }^{15}$ Por. J. Knobe, S. Nichols, An Experimental..., s. 3-14. 
taka powinna być uargumentowana. W przeciwnym razie filozofia eksperymentalna może stać się enklawą, na którą jej krytycy nie będą mieli żadnego wpływu. Podobnie jednak także zwolennicy filozofii eksperymentalnej powinni uwzględnić zarzuty metafilozoficzne oraz wątpliwości, jakie filozofia eksperymentalna budzi wśród tradycyjnych filozofów. Powinni oni starać się wskazywać na uzasadnienie wysnuwania wniosków filozoficznych z badań empirycznych zamiast jedynie stwierdzać, że jest to oczywiste. To także może prowadzić do układu, że filozofia eksperymentalna stanie się enklawą niemającą żadnego wpływu na filozofię analityczną.

Z najostrzejszą krytyką muszą zmierzyć się reprezentanci restrykcjonizmu. Wykorzystywanie wyników badań eksperymentalnych do krytyki eksperymentów myślowych jest, zdaniem pewnej grupy filozofów, co najmniej nieuzasadnione. Wynika to z tego, że filozofowie eksperymentalni przypisują intuicji rolę w rozumowaniu, której — zdaniem krytyków filozofii eksperymentalnej — nie odgrywa. W opinii krytyków filozofii eksperymentalnej intuicja nie odgrywa bowiem roli uzasadniającej w rozumowaniu. Co się z tym zaś wiąże, wykazanie różnic międzygrupowych lub międzyosobniczych w intuicjach, do których odwołują się filozofowie w eksperymentach myślowych, nie podważa tych argumentacji. Koncepcje dotyczące roli intuicji w argumentacjach filozoficznych tworzone przez przeciwników filozofii eksperymentalnej interpretują odwołanie do intuicji jako punkt wyjścia dla dalszych rozważań lub umieszczają je w kontekście odkrycia, a nie uzasadnienia ${ }^{16}$.

Bardziej ogólne zastrzeżenia do badań eksperymentalnych dotyczących intuicji można wysunąć z racji używania w nich pojęcia intuicji. Kirk Ludwig ${ }^{17}$ twierdzi na przykład, że w badaniach eksperymentalnych nie badamy tak naprawdę intuicji, lecz osądy wydawane w konkretnych sytuacjach. Wpływać na nie mogą określone warunki, w jakich prowadzony był eksperyment, czy nowe przekonania, które respondenci nabyli podczas samego eksperymentu. Intuicje mogą być też zniekształcone z powodu niedostatecznego namysłu, niezrozumienia scenariusza czy zwykłej pomyłki. Wąskie rozumienie pojęcia ,intuicji” przez Ludwiga jest niezgodne z rozumieniem go przez wielu innych filozofów, jak chociażby Weinberga i współpracowników, którzy rozumieją intuicje bardzo szeroko i utożsamiają je z niemal wszystkimi reakcjami na eksperymenty myślowe.

W odniesieniu do przywołanych przykładów słuszne wydają się spostrzeżenia Jamesa Andowa ${ }^{18}$. Zarzuca on badaczom właśnie przyjmowanie niedostatecznie jasnego pojęcia intuicji. Jego zdaniem w różnych badaniach, a także w różnych tekstach teoretycznych filozofowie powołują się na pojęcie intuicji bez należytego namysłu, pomijając dookreślenie, co przez dane pojęcie rozumieją. Z tego względu metodologia badań dotyczących intuicji jest jeszcze nienależycie rozwinięta.

${ }^{16}$ Por. m.in. M. Deutsch, Intuitions..., s. 447-460; M. Deutsch, The myth...; H. Cappelen, Philosophy...; H. Cappelen, X-Phi...; D. Chalmers, Intuitions in philosophy: A minimal defense, „Philosophical Studies" 171 [3] (2014), s. 535-544; J. Komorowska-Mach, Negatywny program filozofii eksperymentalnej a odwołania do intuicji w argumentacji filozoficznej, „Filozofia Nauki” 3 [83] (2013), s. 157-165.

17 Por. K. Ludwig, The epistemology..., s. 128-159.

18 Por. J. Andow, Thin, fine and with sensitivity: a metamethodology of intuitions, „Review of Philosophy and Psychology" 7 [1] (2016), s. 105-125. 
Podsumowując rozważania dotyczące kontrowersji wokół filozofii eksperymentalnej, można wskazać na dwie zasadnicze grupy zarzutów. Pierwsza grupa dotyczy kwestii założeń odnośnie do roli intuicji w metodologii filozofii analitycznej i samego pojęcia intuicji. Zdaniem filozofów eksperymentalnych, odwołanie się do intuicji przy okazji eksperymentów myślowych jest hipotezą dotyczącą faktycznego podzielania konkretnej intuicji ${ }^{19}$. Podzielanie konkretnej intuicji jest natomiast rozumiane jako dyspozycja do udzielenia określonej odpowiedzi słownej po zapoznaniu się z jakimś scenariuszem. Przeciwnicy filozofii eksperymentalnej, formułujacc argumenty tego typu, wskazują albo na to, że intuicje nie odgrywają tego typu roli w argumentacjach filozoficznych, albo na to, że intuicje, które są badane przez filozofów eksperymentalnych, nie są tymi samymi intuicjami, do których odwołują się filozofowie w swoich argumentacjach. Druga grupa zarzutów dotyczy kwestii czysto metodologicznych. Można do niej zaliczyć argumenty dotyczące problemów z powtórzeniem osiągniętych wyników przez filozofów eksperymentalnych, użytych bodźców czy doboru grupy.

Niniejszy artykuł zawiera argumenty krytyczne względem filozofii eksperymentalnej zaliczające się do obu grup, jednak ze szczególnym naciskiem na kwestie metodologiczne.

\section{Badanie Weinberga, Nicholsa i Sticha dotyczące intuicji epistemicznych}

\subsection{Wprowadzenie}

Badanie Weinberga, Nicholsa i Sticha można zaliczyć zarówno do nurtu analizy eksperymentalnej, ponieważ jednym z jego celów było skonfrontowanie filozoficznych teorii wiedzy z pojęciem wiedzy w epistemologiach potocznych, jak i do eksperymentalnego restrykcjonizmu ze względu na metodologiczne cele, które przyświecały zespołowi Weinberga. Badanie to dotyczyło różnic międzykulturowych w intuicjach epistemicznych, czyli w intuicjach dotyczacych tego, jaki stan epistemiczny (przekonanie, wiedza) można w danej sytuacji przypisać podmiotowi. Wyniki uzyskane przez Weinberga, Nicholsa i Sticha stanowią empiryczne uzasadnienie tezy głoszacej zróżnicowanie kulturowe intuicji epistemicznych, co według autorów i ich zwolenników ma mieć konsekwencje także dla metodologii filozoficznej. Wyniki badania były szeroko omawiane (artykuł opisujący to badanie był cytowany siedemset piętnaście razy — stan na lipiec 2017 według Google Scholar), spotkały się także z wieloma uwagami krytycznymi, a same eksperymenty doczekały się co najmniej trzech powtórzeń ${ }^{20}$. Żadne z nich nie potwierdziło uzyskanych wcześniej wyników. Jednym z celów wspomnianego badania było skonfrontowanie

19 Por. m.in. J.M. Weinberg, S. Nichols, S. Stich, Normativity..., s. 429-460; T. Wysocki, Filozofia eksperymentalna jako metodologia filozoficzna, http://www.xphi-europe.org/filozofiaeksperymentalna. pdf (dostęp: 2.03.2019).

${ }^{20}$ H. Seyedsayamdost, On normativity..., s. 95-116; J. Nagel, V. San Juan, R. A. Mar, Lay denial..., s. 652-661; M. Kim, Y. Yuan, No cross-cultural..., s. 355-361. 
filozoficznych teorii wiedzy z potocznym pojęciem wiedzy. Drugim celem - metodologicznym - było wykazanie niezasadności korzystania przez filozofów w argumentacji z odwołań do intuicji potocznych. Ze względu na wpływ, który badania Weinberga, Nicholsa i Sticha wciąż wywierają na filozofię eksperymentalną, a także daleko idące wnioski dotyczące rzekomej uniwersalności intuicji epistemicznych wyciągane niekiedy na podstawie przeprowadzonych powtórzeń ${ }^{21}$ dogłębna analiza metodologiczna wspomnianego badania jest bardzo potrzebna. Wydaje się ona niezbędna do tego, aby można było z całą odpowiedzialnością ocenić, co rzeczywiście wnoszą omawiane badania w kwestii międzykulturowego zróżnicowania intuicji epistemicznych.

Głównym celem niniejszego artykułu jest ocena, na ile efekt uzyskany przez Weinberga, Nicholsa i Sticha jest możliwy do powtórnego uzyskania. Wyniki ich badania są bowiem empiryczną podstawą argumentacji za tezą o zróżnicowaniu kulturowym intuicji epistemicznych. Skupiam się więc jedynie na analizie metodologicznej badania Weinberga, Nicholsa i Sticha oraz próbach jego powtórzenia pomimo tego, że eksperymenty nim inspirowane przeprowadzili także John Turri ${ }^{22}$ oraz Edouard Machery z zespołem ${ }^{23}$. Również oni nie odnotowali różnic w intuicjach epistemicznych między reprezentantami odmiennych kultur. Nie analizuję jednak ich wyników z kilku powodów. Po pierwsze ani Turri, ani Machery nigdzie nie piszą, że uważają swoje eksperymenty za powtórzenie badań zespołu Weinberga. Po drugie - w przeciwieństwie do autorów trzech badań, które będą przeze mnie analizowane - ze swoich wyników Turri nie wyciąga daleko idących wniosków negujących rezultaty eksperymentu zespołu Weinberga. Wreszcie, Turri nie korzysta z tych samych scenariuszy, co Weinberg, Nichols i Stich. W przypadku zaś badania Machery'ego i jego zespołu zastosowana jest zupełnie inna metodologia. Jest to związane z faktem, że celem badaczy nie było powtórzenie badania Weinberga, Nicholsa i Sticha. Machery i jego zespół badali wpływ kultury na intuicje epistemiczne zgodnie z przyjętymi przez siebie założeniami teoretycznymi dotyczącymi między innymi wpływu języka na intuicje, różniącymi się od tych, które przyjęli Weinberg, Nichols i Stich. Zespół Machery'ego przyjmował bowiem koncepcję, zgodnie z którą intuicje mają podłoże językowe — są więc uzależnione od tego, w jakim języku są formułowane.

Wyniki analiz przedstawionych w tym artykule mogą być rozumiane jako argumenty z obu omówionych grup przeciwko wskazanym tezom sformułowanym przez Weinberga, Nicholsa i Sticha. Przedstawię głównie argumenty natury metodologicznej. Jednak sformułuję również zarzut dotyczący trafności treściowej badania Weinberga, Nicholsa i Sticha, który dotyczy błędnego przyjęcia znaczenia pojęcia intuicji.

${ }^{21}$ Por. m.in. M. Kim, Y. Yuan, No cross-cultural..., s. 359-361. M. Kim, Y. Yuan, Cross-Cultural Universality in Knowledge Attributions, https://philpapers.org/archive/YUACUO.pdf (dostęp: 2.03.2019).

${ }^{22}$ J. Turri, A conspicuous art: Putting Gettier to the test, „Philosophers' Imprint” 13 [10] (2013), s. $1-16$.

${ }^{23}$ E. Machery et al., Gettier across cultures, „Noûs” 50 [2] (2015), s. 1-20. 
Badania Nagel, San Juan i Mar ${ }^{24}$, Seyedsayamdosta ${ }^{25}$ oraz Kim i Yuan ${ }^{26}$ analizuję w znacznej mierze właśnie jako próby powtórnego osiągnięcia tych samych wyników przy możliwie podobnej metodologii, a nie jako samodzielne badania. Krytykując ich metodologię, zakładam więc, że ich celem jest potwierdzenie lub sfalsyfikowanie istnienia efektu, który Weinberg, Nichols i Stich zaobserwowali w stworzonych przez siebie warunkach eksperymentalnych. Zatem na przykład przez dobrą operacjonalizację zmiennych rozumiem taką, która jest maksymalnie zbliżona do tej zastosowanej w badaniu oryginalnym, a niekoniecznie tę, która z różnych względów może wydawać się trafniejsza.

Poczynione założenie postaram się uzasadnić w odniesieniu do rozróżnienia między replikacją ścisłą i pojęciową. Niektórzy metodologowie ${ }^{27}$ przekonują, że replikacja ścisła, a więc maksymalnie zbliżona pod względem warunków i metodologii do badania powtarzanego, chroni przed fałszowaniem badań, nieuprawnionym generalizowaniem wyników na większą lub inną populację oraz pozwala kontrolować trafność wewnętrzną (wykluczyć lub wskazać artefakty zaburzające wyniki). Do ostatecznego sfalsyfikowania tezy konieczne jest natomiast przeprowadzenie replikacji pojęciowej, przeprowadzonej w innych warunkach niż badanie pierwotne, które nie powinny mieć wpływu na jego przebieg. Zatem wydawałoby się, że na przykład zastosowanie operacjonalizacji zmiennych bardziej trafnych lecz odmiennych niż w badaniu pierwotnym jest praktyką pożądaną i uzasadnioną. Mimo to omawiane replikacje będę rozpatrywać jako replikacje ścisłe z kilku powodów. Należy zwrócić uwagę, że badania nad intuicjami epistemicznymi filozofowie eksperymentalni prowadzą dopiero od początku XXI wieku. Wiedza o czynnikach wpływających na intuicje epistemiczne wciąż jest niewielka. Z jednej strony już do tej pory wskazano wiele, bardzo specyficznych czynników wpływających na intuicje epistemiczne, z drugiej zaś wiele efektów uzyskanych przez jednych badaczy nie udaje się uzyskać innym ${ }^{28}$. Oznacza to, że przeprowadzenie replikacji pojęciowej badania Weinberga, Nicholsa i Sticha jest wyjątkowo trudne ze względu na bardzo duże niebezpieczeństwo niedoszacowania możliwego wpływu na wyniki czynników niewziętych pod uwagę przy konstruowaniu badania. Należy tė̇ zwrócić uwagę, że nawet zwolennicy przeprowadzania replikacji pojęciowych wskazują przede wszystkim na jej znaczenie na późnym etapie prowadzenia badań nad danym zagadnieniem ze względu na to, że niesie ona informacje objaśniające dane zjawisko, a nie tylko potwierdzające je lub odrzucające. Na wczesnym etapie badań, przy podejrzeniu fałszywości badanego efektu, pożądane jest natomiast przeprowadzanie replikacji ścisłej. Wreszcie, przeprowadzona przeze mnie analiza metodologiczna traktuje replikacje jako ścisłe także z tego powodu, że

24 J. Nagel, V. San Juan, R.A. Mar, Lay denial..., s. 652-661.

${ }^{25}$ H. Seyedsayamdost, On normativity..., s. 95-116.

${ }^{26}$ M. Kim, Y. Yuan, No cross-cultural..., s. 355-361.

27 Por. m.in. S. Schmidt, Shall we really do it again? The powerful concept of replication is neglected in the social sciences, „Review of General Psychology” 13 [2] (2009), s. 90-100; J. Hüffmeier, J. Mazei, T. Schultze, Reconceptualizing replication as a sequence of different studies: A replication typology, „Journal of Experimental Social Psychology” 66 (2016), s. 81-92.

28 Por. E.T. Kerr, Epistemological Experiments and Empirical Philosophy in Cross-Cultural Contexts, „Asia Research Institute Working Paper Series” 233 (2015), s. 1-27. 
wskazane przeze mnie problemy omawianych badań z trafnością treściową w części piątej są w istocie krytyką prób powtórzeń badania Weinberga, Nicholsa i Sticha rozumianych jako replikacje pojęciowe.

\subsection{Metodologia, założenia i przebieg badania Weinberga, Nicholsa i Sticha}

W artykule Normativity and Epistemic Intuitions Weinberg, Nichols i Stich opisali badanie dotyczące powszechności intuicji epistemicznych. Jako inspirację wskazywali wyniki Richarda Nisbetta oraz Jonathana Haidta. Pierwszy jest autorem prac dotyczących różnic w procesach poznawczych (działania pamięci, uwagi czy percepcji) u osób z kultur zachodnich i azjatyckich ${ }^{29}$. Zespół drugiego eksperymentalnie dowodził różnic w intuicjach moralnych u osób o różnym statusie socjoekonomicznym (SES) ${ }^{30}$.

Powołując się na te badania, Weinberg, Nichols i Stich stawiają cztery hipotezy:

H1. Intuicje epistemiczne są zróżnicowane międzykulturowo.

H2. Intuicje epistemiczne są zależne od statusu socjoekonomicznego.

H3. Intuicje epistemiczne są zależne od liczby przebytych kursów o tematyce filozoficznej.

H4. Intuicje epistemiczne, przynajmniej częściowo, są zależne od tego, w jakiej kolejności badani rozważają podawane im przykłady.

Pod pojęciem intuicji epistemicznych Weinberg, Nichols i Stich rozumieją wszelkie reakcje (w tym słowne) na przedstawione im eksperymenty myślowe, w których można przypisać bohaterom różne stany epistemiczne. Badacze skoncentrowali się głównie na pierwszej hipotezie, dlatego ja również skupię się w swoim artykule głównie na niej.

Aby przetestować H1 Weinberg, Nichols i Stich podzielili grupę badawczą ze względu na kulturę, z której wywodzili się badani (wszyscy badani byli studentami w Stanach Zjednoczonych). Powstały w ten sposób trzy grupy: osób pochodzących ze Stanów Zjednoczonych bądź Europy Zachodniej („Amerykanie i Europejczycy”), Azji Wschodniej („Azjaci Wschodni”) lub subkontynentu indyjskiego („Hindusi”).

Badanym przedstawiane były różnego rodzaju scenariusze, w których z pewnych powodów można było mieć wątpliwości co do tego, czy ich bohater dysponuje wiedzą na dany temat. Większość historyjek zaczerpnięto z tekstów, w których były one używane jako eksperymenty myślowe. Dużą grupą tego typu przykładów są tak zwane sytuacje gettierowskie - inspirowane lub zaczerpnięte wprost z artykułu Is justified true believe knowledge? ${ }^{31}$ — polski przekład: Czy uzasadnione

${ }^{29}$ Por. R.E. Nisbett et al., Culture and systems of thought: holistic versus analytic cognition, „Psychological Review" 108 [2] (2001), s. 291-310.

${ }^{30}$ Por. J. Haidt, S.H. Koller, M.G. Dias, Affect, culture, and morality, or is it wrong to eat your dog?, ,Journal of Personality and Social Psychology” 65 [4] (1993), s. 613-628.

31 E.L. Gettier, Is justified true belief knowledge?, „Analysis” 23 [6] (1963), s. 121-123. 
$i$ prawdziwe przekonanie jest wiedza? $?^{32}$ — autorstwa Edmunda Gettiera. Maja one podważać klasyczną definicję wiedzy, zgodnie z którą jest ona przekonaniem prawdziwym i uzasadnionym.

Scenariusz, który jest najczęściej przytaczanym przykładem w dyskusjach dotyczących omawianej pracy, wyglądał następująco:

Julia i samochód (JiS): „Bartek ma znajomą Julię. Pamięta, że Julia przez wiele lat jeździła samochodem amerykańskiej marki Buick. Sądzi więc, że Julia jeździ amerykańskim samochodem. Nie wie jednak, że Julia niedawno sprzedała ten samochód i kupiła inny, marki Pontiac, która również jest amerykańska"33.

Po zapoznaniu się z historyjką osoby badane miały za zadanie zadecydować, czy w opisanej sytuacji ich bohater dysponował wiedzą, czy miał jedynie przekonanie. W tym wypadku należało wybrać jedną z dwóch możliwych odpowiedzi: zgodnie z pierwszą Bartek naprawdę wie, że Julia jeździ amerykańskim samochodem, zgodnie z drugą jest o tym jedynie przekonany.

Wyniki potwierdzające H1 — istnienie różnic międzykulturowych — dało się zaobserwować w kilku różnych scenariuszach, również w opisanej historii JiS (wykres 1).

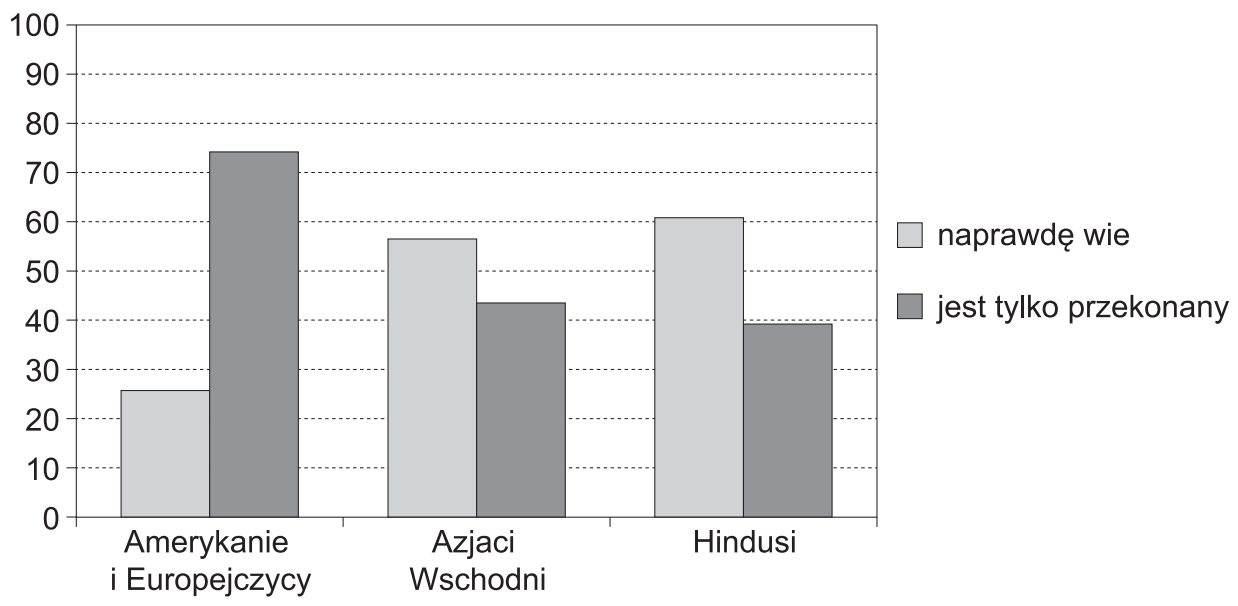

Wykres 1. Wyniki eksperymentów Weinberga, Nicholsa i Sticha (przykład JiS) Źródło: opracowanie własne.

\subsection{Kontrowersje metodologiczne związane $\mathrm{z}$ badaniem Weinberga, Nicholsa i Sticha}

Niżej przedstawię różnego rodzaju zarzuty metodologiczne, które można postawić badaniu Weinberga, Nicholsa i Sticha. Najważniejsze będą dotyczyć trafności, transparentności, liczebności prób oraz ich doboru.

32 J. Hartman, J. Robus, Czy uzasadnione i prawdziwe przekonanie jest wiedza?, „Principia” 1(1990), s. $93-96$.

33 Cyt. za: J.M. Weinberg, S. Nichols, S. Stich, Normativity..., s. 443, tłum. własne. 


\section{Liczebność próby}

Jednym z najczęstszych zarzutów formułowanych pod adresem badania zespołu Weinberga jest bardzo mała grupa badawcza, zwłaszcza jeśli chodzi o grupy Azjatów Wschodnich i Hindusów. Na ten fakt zwrócili uwagę wszyscy badacze, którzy podjęli się powtórzenia wyników. W żadnym z eksperymentów nie wzięło bowiem udziału więcej Azjatów Wschodnich niż trzydziestu jeden, a interesująca nas historyjką JiS przebadanych zostało jedynie dwudziestu trzech. W eksperymencie o najmniejszej grupie badanych porównano grupę dziesięciu Amerykanów i Europejczyków oraz trzydziestu jeden Azjatów Wschodnich. Również w przypadku eksperymentów z udziałem Hindusów uwagę zwracają wyjątkowo małe grupy badanych, które liczą od dwudziestu dwóch do dwudziestu czterech osób. Liczebność tego rzędu niesie za sobą poważne zagrożenia. Tak nieliczna grupa może być po prostu niereprezentatywna - im mniejsza grupa, tym większa szansa na wpływ czynników losowych na ostateczny wynik badania. Dlatego tė̇ niska liczebność grupy zmniejsza moc testu, a więc zwiększa prawdopodobieństwo wystąpienia błędu drugiego rodzaju, czyli przyjęcia hipotezy zerowej (w tym wypadku, że intuicje epistemiczne nie są zróżnicowane międzykulturowo), podczas gdy jest ona w rzeczywistości fałszywa ${ }^{34}$.

\section{Reprezentatywność próby}

Kontrowersyjną kwestią jest również sam dobór badanych. Kwestionariusz, za pomocą którego osoby badane były przydzielane do odpowiedniej grupy, nie został w artykule Weinberga, Nicholsa i Sticha w ogóle opisany. Jedyne co wiadomo na jego temat, to fakt, że zespół Weinberga otrzymał go od Nisbetta, który korzystał z niego przy swoich badaniach międzykulturowych. Jednak również w artykułach Nisbetta, do których Weinberg i jego zespół się odnoszą, kwestionariusz ten nie jest szerzej opisany. Wydaje się to nie tylko problemem dla badaczy chcących przeprowadzić ewentualne powtórzenia badania, lecz także w znacznej mierze uniemożliwia w ogóle ocenę metody wyznaczania pochodzenia osób badanych. Jest to tym bardziej zaskakujące, że również w przypadku jednego z powtórzeń (Hamida Seyedsayamdosta) autor wspomina o „demograficznym instrumencie Nisbetta”. Seyedsayamdost odnosi się do publikacji Weinberga i jego zespołu ${ }^{35}$ oraz artykułu Nisbetta i innych ${ }^{36}$, w którym explicite nie ma opisanej metody podziału grup ze względu na kulturę. Ewentualna możliwość zapoznania się z danym kwestionariuszem po osobistej prośbie skierowanej do Richarda Nisbetta nie wydaje się rozwiązywać problemu. Kwestionariusz ten jest udostępniany na życzenie (chciałbym w tym miejscu podziękować profesorowi Richardowi Nisbettowi za przesłanie mi owego scenariusza). Jednak nie ma w nim metody interpretacji wyników, a zawiera on aż osiemnaście pytań dotyczących między innymi miejsca urodzenia, języka ojczystego czy wyznawanej wiary. Oznacza to, że samo zapoznanie się z kwestiona-

${ }^{34}$ Por. Ł. Budzicz, Wartość poznawcza badań empirycznych w psychologii społecznej, niepublikowana rozprawa doktorska, Uniwersytet Adama Mickiewicza w Poznaniu 2015, s. 37-39; J.P. Ioannidis, Why most published research findings are false, „PLoS medicine” 2 [8] (2005), s. 696-697.

35 J.M. Weinberg, S. Nichols, S. Stich, Normativity..., s. 429-460.

36 R.E. Nisbett et al., Culture..., s. 291-310. 
riuszem nie wystarczy do ustalenia, jakie odpowiedzi upoważniają do przypisania danego badanego do odpowiedniej grupy. Te same odpowiedzi w zależności od przyjętej ich interpretacji mogą prowadzić do odmiennych wniosków.

Niestety, badaniu zespołu Weinberga można zarzucić też brak transparentności z wielu innych jeszcze powodów. Oprócz powołania się na kwestionariusz w artykule Normativity and Epistemic Intuitions nie opisano dokładnie samej procedury badawczej (na przykład kolejności wypełnianych kwestionariuszy), rozkładu wieku czy płci badanych.

Warto zwrócić uwagę na fakt, że eksperymenty przeprowadzono na studentach mieszkających w New Jersey, co więcej, podczas zajęć na uniwersytecie. Powstaje pytanie o motywację osób badanych oraz presję wywołaną faktem przeprowadzania na nich badania przez ich własnych wykładowców. Fakt zamieszkania wszystkich badanych w New Jersey nasuwa też inną wątpliwość. Istnieje wysokie prawdopodobieństwo, że badani byli w rzeczywistości drugim lub trzecim pokoleniem emigrantów osiedlonych w Stanach Zjednoczonych, a nie osobami, które stykały się głównie z inną kulturą niż zachodnia. Stawia to pod znakiem zapytania tezę, czy rzeczywiście różnice wskazane przez Weinberga i jego zespół dotyczą właśnie różnic międzykulturowych. Trudno ocenić, na ile kolejne pokolenie emigrantów jest reprezentatywne dla grupy etnicznej swoich przodków. Nie bez znaczenia wydaje się, że grupa ta w Stanach Zjednoczonych odznacza się na przykład niższym statusem socjoekonomicznym (SES), spowodowanym między innymi mniejszym kapitałem kulturowym ${ }^{37}$. Niższy SES nie jest przy tym immanentną cechą Azjatów czy Hindusów, a jedynie wynikiem konkretnej sytuacji imigrantów w Stanach Zjednoczonych. Wreszcie warto zauważyć, że grupa badanych składała się ze studentów kierunków humanistycznych. Tego typu dyscypliny w 2009 roku studiowało $22,9 \%^{38}$ studentów, przy czym spośród Azjatów takiego wyboru dokonało niespełna 15\% studentów, a w latach 2013-2015 jedynie 10\%39. Fakt, że osoby wybierające kierunki humanistyczne to grupa dość specyficzna, zwłaszcza w przypadku imigrantów i ich dzieci (w tym wypadku z krajów azjatyckich), skłania do refleksji nad reprezentatywnością grupy badanych.

\section{Trafność}

Pewnym aspektem zaburzającym trafność badania zespołu Weinberga jest sama konstrukcja pytań pod koniec historyjek. Badani mieli do wyboru dwie odpowiedzi: mogli uznać, że bohater historyjki coś ,rzeczywiście wiedział” lub ,jedynie był przekonany". Weinberg, Nichols i Stich nadają w ten sposób dużą wartość normatywną wiedzy i sugerują znaczącą różnicę między nią a przekonaniem. Co więcej, można odnieść wrażenie, że w wypadku przekonania bycie „,jedynie przekonaniem”

${ }^{37}$ Por. E. Shackelford, R.A. Smith, Issue Brief: Immigration and Socioeconomic Status, publikacja pokonferencyjna: „Race and Ethnicity in American Politics” 2010; J. Kucharska, Problemy psychiczne w grupach mniejszości etnicznych i narodowych, „Psychiatria Polska” 46 [3] (2012), s. 453-455.

${ }^{38}$ Por. Field of Bachelor's Degree in the United States, American Community Survey Reports 2009.

39 Por. International Student Enrollment Trends, 1948/49-2014/15 (2015), Open Doors Report on International Educational Exchange, https://www.iie.org/Research-and-Insights/Open-Doors/Data/ International-Students/Enrollment-Trends (dostęp: 4.03.2019). 
jest wyjątkowo deprecjonujące, być może też sugerujące fałszywość, choć przypomnijmy, że przekonania bohaterów historyjek są w rzeczywistości prawdziwe. Tak sformułowany wybór może zniekształcać odpowiedzi badanych przez narzucenie im podzielanych przez zespół Weinberga poglądów dotyczących rozróżnienia między wiedzą a przekonaniem, w szczególności wyraźnej opozycji w opisywanych wypadkach. Zresztą sami autorzy Normativity and Epistemic Intuitions zaznaczają, że specyficzne dla epistemologii zachodniej jest uważanie wiedzy za coś dobrego, wartościowanie jej pozytywnie ${ }^{40}$. Jednak pogląd ten może nie być podzielany przez przedstawicieli innych kultur, jest jednak uwidoczniony i narzucony w sformułowaniu możliwych odpowiedzi.

Wreszcie warto zwrócić uwagę na toczącą się dyskusję na temat możliwości badania samych intuicji, możliwości ich naturalizacji, zwłaszcza w odniesieniu do bardzo liberalnej interpretacji, jaką posłużyli się Weinberg, Nichols i Stich. Określili oni intuicje jako wszelkie reakcje na eksperymenty myślowe. Takie rozumienie budzi jednak kontrowersje $\mathrm{e}^{41}$. Do warunków, które muszą spełniać intuicje istotne z perspektywy metodologii filozofii, a których nie uwzględniono w omawianych badaniach, niektórzy zaliczają między innymi refleksję poprzedzającą odpowiedź lub wykształcenie filozoficzne. Niektórzy, jak Ludwig czy Kaupinnen, twierdzą wręcz, że badanie tego typu intuicji za pomocą metod nauk społecznych jest niemożliwe.

W tym miejscu przejdę do analizy metodologicznej każdego z trzech powtórzeń badania zespołu Weinberga, a także odniosę się do tego, na ile rzeczywiście te badania spełniają swój cel zweryfikowania możliwości powtórnego osiągnięcia tych samych wyników przy możliwie podobnej metodologii oraz na ile uderzają one w oryginalne wyniki uzyskane przez Weinberga, Nicholsa i Sticha.

\section{Powtórzenia badania Weinberga, Nicholsa i Sticha}

\subsection{Pierwsze powtórzenie. Badanie Nagel, San Juan i Mara}

Pierwszą chronologicznie próbą powtórzenia wyników Weinberga, Nicholsa i Sticha były badania Nagel, San Juan i Mara ${ }^{42}$. Składały się one z kilkunastu eksperymentów, z których większość znaczne odbiegała od oryginalnych badań. Wśród nich było jednak jedno, którego cel wprost określono jako powtórzenie wyników opisanych w Nomativity and Epistemic Intuitions. Ponieważ jednak Nagel, San Juan i Mar wyciągają wnioski na temat uniwersalności intuicji i miarodajności wyników Weinberga, Nicholsa i Sticha, biorąc pod uwagę wszystkie przeprowadzone przez siebie eksperymenty, opiszę i poddam krytyce metodologię także zmodyfikowanych eksperymentów opisanych przez zespół Nagel.

Podobnie jak w przypadku badania Weinberga, Nicholsa i Sticha zespół Nagel, San Juan i Mara przedstawiał badanym serię historyjek oraz prosił o wybór zdania

${ }^{40}$ Por. J.M. Weinberg, S. Nichols, S. Stich, Normativity..., s. 431.

${ }^{41}$ Por. m.in. J. Andow, Thin, fine and with sensitivity: a metamethodology of intuitions, ,Review of Philosophy and Psychology" 7 [1] (2016), s. 105-125; K. Ludwig, The Epistemology..., s. 128-59; A. Kauppinen, The rise..., s. 95-118.

42 J. Nagel, V. San Juan, R. A. Mar, Lay denial..., s. 652-661. 
przypisującego ich bohaterom wiedzę lub samo przekonanie. Co istotne, między oboma badaniami zachodzą znaczne różnice metodologiczne.

\section{Liczebność i dobór próby}

Grupa badawcza składała się z dwustu trzydziestu ośmiu kanadyjskich studentów pierwszego stopnia, z których szesnaście osób nie ukończyło badania, a czternaście zostało wykluczonych ze względu na zbyt szybkie rozwiązanie zadań (fakt ten został uznany za wskaźnik udzielania losowych lub nieprzemyślanych odpowiedzi). Warto zwrócić uwagę, że w oryginalnym eksperymencie Weinberga, Nicholsa i Sticha nie przeprowadzono tego typu selekcji. O ile więc rzeczywiście może ona być traktowana jako metodologicznie uzasadniona, o tyle odbiera to siłę badaniu zespołu Nagel jako próby powtórzenia wyników badania Weinbrga, Nicholsa i Sticha przy zachowaniu możliwie podobnej metodologii. Dzieje się tak zwłaszcza ze względu na to, że zespół Weinberga badał studentów, którzy rozwiązywali testy na zajęciach, co, jak pisałem, może sprzyjać niskiej motywacji i sprawiać, że odpowiedzi mogą być nieprzemyślane lub w znacznej mierze losowe. Skądinąd w wypadku badania intuicji dyskusyjne jest arbitralne uznanie jakiegoś czasu jako zbyt krótkiego do udzielenia dostatecznie przemyślanej odpowiedzi. Samo zresztą narzucenie konieczności namysłu przed odpowiedzią jest już pewnym nieoczywistym założeniem modyfikującym definicję intuicji, która przez Weinberga i jego zespół była opisana jako każda reakcja słowna na scenariusz. Kwestia ewentualnej konieczności namysłu przed udzieleniem odpowiedzi jest przedmiotem żywych dyskusji nad pojęciem intuicji i możliwości ich badania przez filozofię eksperymentalną.

Choć na pierwszy rzut oka liczba przebadanych osób wydaje się duża, warto zwrócić uwagę, że zostali oni podzieleni na sześć grup etnicznych z czego grupy, które pojawiały się w badaniu Weinberga, Nicholsa i Sticha, u Nagel liczyły odpowiednio: Amerykanie i Europejczycy — siedemdziesiąt osób, Hindusi — pięćdziesiąt trzy i Azjaci Wschodni — dwadzieścia cztery osoby. W wypadku dwóch pierwszych grup miarodajność nowszych badań jest wyższa, należy więc odnotować znaczną poprawę. Liczebność grupy Azjatów Wschodnich nie odbiega jednak od krytykowanej, małej liczebności w oryginalnym badaniu.

Do grup etnicznych badani zostali przydzieleni na podstawie samoidentyfikacji. Także ten fakt budzi pewne kontrowersje, zarówno jeśli analizujemy badanie zespołu Nagel jako powtórzenie, jak i wtedy, gdy po prostu oceniamy trafność takiej właśnie operacjonalizacji zmiennej. W oryginalnym badaniu respondenci zostali podzieleni na grupy za pomocą kwestionariusza, który oprócz pytania o samoidentyfikację etniczną zawierał także pytania faktualne (dotyczące faktów, a nie na przykład opinii czy ocen) wpływające na ostateczną klasyfikację badanych. Można więc mieć wątpliwość, na ile metody podziału na grupy w obu badaniach odpowiadają sobie nawzajem.

Również sama samoidentyfikacja etniczna jako metoda podziału na grupy budzi kontrowersje. Jak każda metoda samoopisowa obarczona jest bowiem specyficznym ryzykiem przekłamania ${ }^{43}$.

${ }^{43}$ Por. m.in. R.E. Davis et al., Interviewer effects in public health surveys, „Health education research" 25 [1] (2010), s. 14-26; L. Hall, P. Johansson, T. Strandberg, Lifting the Veil of Morality: 


\section{Procedura}

Badanie przeprowadzono online (co stanowi kolejną odmienność względem badań Weinberga, Nicholsa i Sticha). Najpierw badani wypełniali część, w której zapoznawali się z historyjkami i przypisywali ich bohaterom wiedzę lub jedynie przekonanie. Następnie uzupełniali kwestionariusz demograficzny (płeć, wiek, grupa etniczna, liczba odbytych kursów filozoficznych). Na końcu wypełniali Toronto Empathy Questionaire dotyczący poziomu empatii, a także część sprawdzającą, na ile dobrze zapamiętali szczegóły dotyczące historyjek oraz na ile są pewni swoich odpowiedzi (na pięciostopniowej skali Likerta).

\section{Wstepne warunki}

Interesujący jest proces analizy w badaniach Nagel, San Juan i Mara. Aby mieć pewność, że badani jako wiedzę rozumieją prawdziwe i uzasadnione przekonanie tuż przed częścią, w której wprost przypisywali bohaterom wiedzę lub jej brak, musieli odpowiedzieć na kilka pytań wstępnych. Jeśli na któreś z nich udzielili odpowiedzi, z której wynikało, że nie przypisują bohaterowi przekonania lub uważają, że jest ono nieprawdziwe, automatycznie byli przenoszeni do ostatniej części kwestionariusza (z pominięciem pytania o posiadanie wiedzy przez bohatera). Osobom takim nie zadawano kolejnych pytań i nie uwzględniano ich w analizach. Celem tego zabiegu było doprowadzenie do sytuacji, w której bez wątpienia wiedza przypisywana bohaterom rzeczywiście była rozumiana jako prawdziwe i uzasadnione przekonanie.

\section{Pytania do scenariuszy $i$ wstępna analiza}

Jeśli rozpatrujemy badanie zespołu Nagel jako powtórzenie, problematycz na okazuje się forma pytania o przekonania bohatera. Brzmiało ono bowiem: „Czy bohater jest przekonany, że X?”. Zatem w przykładzie JiS zadawano pytanie: „Czy Bartek jest przekonany, że Julia jeździ amerykańskim samochodem?”. Istotne jest to, że do wyboru były jedynie odpowiedzi „tak”/,nie”. W przypadku odpowiedzi negatywnej osobie przypisywane było przekonanie, że Bartek nie wie, że Julia jeździ amerykańskim samochodem. Dość jasne wydaje się jednak, że istnieją przypadki, w których osoby badane mogły zaznaczać „nie”, ponieważ uważały, że Bartek nie tylko jest przekonany, ale wręcz wie, że Julia jeździ amerykańskim samochodem. Jest to oczywiście hipoteza, jednak wydaje się, że tak sformułowane pytanie grozi przedwczesnym przypisaniem niektórym badanym konkretnego poglądu, którego w rzeczywistości nie podzielają. Jeśli moja hipoteza jest słuszna, istotnie obniża to wartość badania zespołu Nagel.

Warto w tym miejscu wspomnieć, jak dosłownie były sformułowane pytania i odpowiedzi w badaniu Nagel, San Juan i Mara. Było ono przeprowadzone w języku angielskim. Pytanie w tym badaniu brzmiało: „Does agent think that X?” — ze względu na to, że pytanie to ma sprawdzać warunek przypisania bohaterowi

Choice Blindness and Attitude Reversals on a Self-Transforming Survey, „PLoS ONE” 7 [9] (2012), s. 1-8; R.E. Nisbett, T.D. Wilson, Telling more than we can know: Verbal reports on mental processes, „Psychological Review” 84 [3] (1977), s. 231-259; N. Schwarz, Self reports: how the questions shape the answers, „American Psychologist” 54 [2] (1999), s. 93-105; W. Von Hippel, R. Trivers, The evolution and psychology of self-deception, „Behavioral and Brain Sciences” 34 [1] (2011), s. 1-16. 
przekonania, w tekście przetłumaczyłem słowo think na „,jest przekonany”. Jednak warto zwrócić uwagę na to, że angielski czasownik to think może być traktowany jako opisujący stan mniejszej pewności niż ten opisywany przez czasownik to believe, który był używany przy pytaniach o stan epistemiczny bohatera historyjki na przykład w badaniu Weinberga, Nicholsa i Sticha. Te niuanse semantyczne maja duże znaczenie dla opisywanego przeze mnie zarzutu wobec metodologii badania Nagel, San Juan i Mara.

Nagel, San Juan i Mar wprowadzili ponadto jeszcze inną istotną zmianę w badaniu. W zasadniczej jego części, w której należało bohaterom przypisać wiedzę lub jej brak, autorzy zmienili możliwe do wyboru odpowiedzi. Wynikało to ze wspomnianego zarzutu pod adresem Weinberga, Nicholsa i Sticha sformułowanego między innymi przez Cullena ${ }^{44}$, że pytania zespołu Weinberga presuponowały normatywne własności wiedzy. Przypomnijmy, że pytania w oryginalnym badaniu były sformułowane: „Czy podmiot wie, że X?”, a możliwe odpowiedzi to: „Naprawdę wie" i „Jest jedynie przekonany".

Aby uniknąć podobnych zarzutów, zespół Nagel, pozostawiając taką samą strukturę pytań, dał badanym do wyboru jedną z trzech odpowiedzi: (1) „Tak, wie”, (2) „Nie, nie wie” i (3) „Niejasne. Brak wystarczających informacji w historyjce”. Następnie badani, którzy wybrali odpowiedź (1), musieli ustosunkować się do dwóch stwierdzeń, wybierając, które z nich lepiej ich zdaniem pasuje do historyjki: (a) „Podmiot wie, że X”, (b) „Podmiot ma poczucie, że wie, że X, jednak faktycznie, nie wie, że X”. Badanym, którzy udzielili odpowiedzi (2), przypisywano „Natychmiastowe odmówienie wiedzy”. Tym, którzy udzielili odpowiedzi (1), a następnie (b) przypisywano „Odwleczone odmówienie wiedzy”. Badanym, którzy natomiast wybrali odpowiedzi (1) oraz (a) przypisano „Niezachwiane przypisanie wiedzy”. Zabieg ten (zmiana możliwych odpowiedzi i specyficzna analiza włącznie z drugą serią pytań) rzeczywiście może poprawiać rzetelność badania (którego przedmiotem są intuicje dotyczące wiedzy jako prawdziwego uzasadnionego przekonania), nie narzucając utajonych przekonań na temat pojęcia wiedzy. Jednak zdecydowanie zaburza on wartość badania jako próby powtórzenia badania Weinberga, Nicholsa i Sticha.

Można też jednak wysunąć pewien zarzut do przedstawionego sposobu analizy odpowiedzi. Jest to podobny problem, co omawiana już kwestia odrzucenia badanych, którzy we wstępnych pytaniach rzekomo nie przypisywali bohaterom scenariuszy przekonań. Zauważmy, że wykluczeni z analizy zostali też ci, którzy udzielili odpowiedzi (3). Tych osób nie wykluczano z badań zespołu Weinberga, a zatem w kolejnym miejscu zaburzona jest wartość eksperymentów Nagel, San Juan i Mara jako próby powtórzenia wyników badania Weinberga, Nicholsa i Sticha przy zachowaniu możliwie podobnej metodologii.

Zespół Nagel nie odnotował różnic międzykulturowych w odpowiedziach swoich badanych, w tym również w wypadku przykładu JiS (wykres 2). Omówione zarzuty metodologiczne związane zarówno z grupą badawczą (w szczególności wykluczanie badanych ze względu na określone odpowiedzi), jak i samą procedurą badawczą

${ }^{44}$ Por. S. Cullen, Survey-driven romanticism, „Review of Philosophy and Psychology” 1 [2] (2010), s. $275-296$. 
(w tym kwestie sformułowania odpowiedzi) podaja jednak w wątpliwość wartość tego badania z perspektywy celu, jakim było potwierdzenie lub sfalsyfikowanie efektu otrzymanego przez zespół Weinberga.

\subsection{Drugie powtórzenie. Badania Seyedsayamdosta}

W 2015 roku Hamid Seyedsayamdost opublikował artykuł ${ }^{45}$, w którym przedstawił własne próby powtórzenia wyników uzyskanych przez zespół Weinberga. Jego badania dotyczyły zarówno różnic międzykulturowych w zakresie intuicji epistemicznych, jak i różnic ze względu na status socjoekonomiczny. Ze względu na cel niniejszego artykułu interesujące będą zwłaszcza te pierwsze.

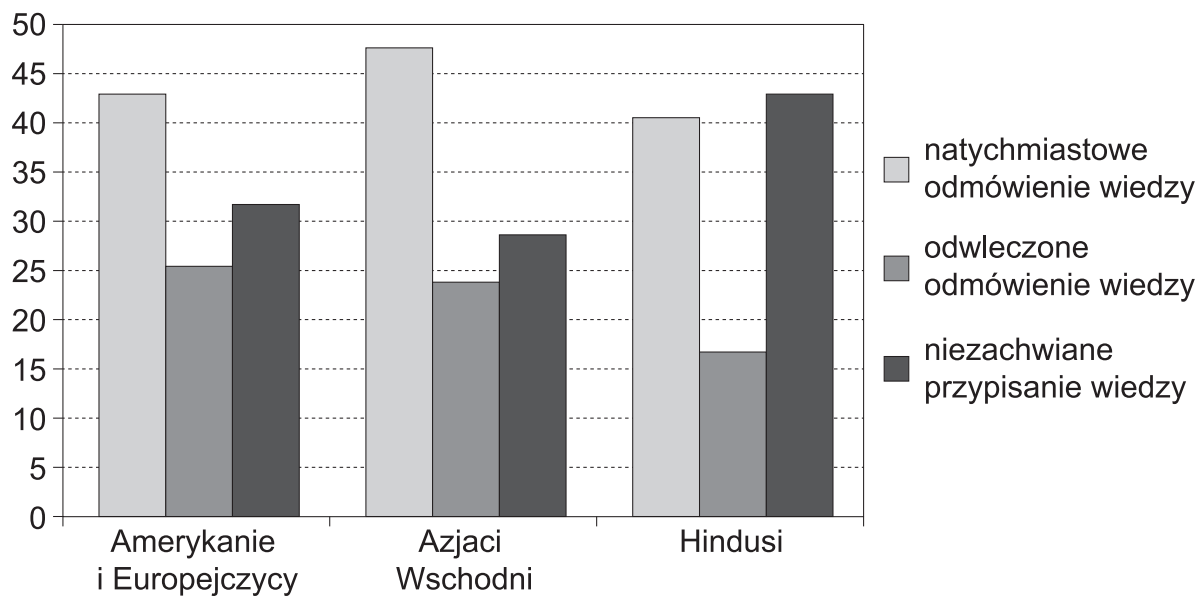

Wykres 2. Wyniki badań Nagel, San Juan i Mara dla przykładu JiS

Źródło: opracowanie własne.

Pierwsze badanie Seyedsayamdosta: dobór i liczebność próby, procedura

Seyedsayamdost przedstawił wyniki uzyskane w czterech badaniach. Pierwsze przeprowadzono na studentach pierwszego stopnia wydziałów filozoficznych oraz stosunków międzynarodowych w London School of Economics (LSE). Do grup etnicznych badani zostali przydzieleni na podstawie skróconego kwestionariusza demograficznego Nisbetta. Autor zaznacza, że korzystał z tego samego narzędzia, którego używał zespół Weinberga, chociaż ze względu na to, że jego badanie było krótsze, skrócił również kwestionariusz tak, by zawierał jedynie pytania bezpośrednio związane z kwestią pochodzenia. W ten sposób uzyskał grupy Amerykanów i Europejczyków, Hindusów i Azjatów Wschodnich, liczące odpowiednio siedemdziesiąt dziewięć, trzydzieści siedem i czterdzieści jeden osób. Po krótkim wprowadzeniu badani wypełniali skrócony kwestionariusz Nisbetta oraz zapoznawali się z jedną historyjką - JiS. Następnie mieli wybrać jedną z dwóch możliwości doty-

${ }^{45}$ H. Seyedsayamdost, On normativity..., s. 95-116. 
czaccych stanu epistemicznego jej bohatera. Tak jak w przypadku badania zespołu Weinberga, możliwości brzmiały „naprawdę wie” oraz ,jest jedynie przekonany”.

Badanie to, z czterech przedstawionych przez Seyedsayamdosta, jest najbliższe metodologicznie badaniom zespołu Weinberga. Jednak także w jego wypadku można wskazać na pewne kwestie podważające jego wartość jako próby powtórzenia wyników badania Weinbrga, Nicholsa i Sticha przy zachowaniu możliwie podobnej metodologii.

\section{Pierwsze badanie Seyedsayamdosta - kontrowersje}

Przede wszystkim kontrowersyjne jest skrócenie kwestionariusza, którego Seyedsayamdost użył do klasyfikacji badanych pod względem ich przynależności etnicznej. Pomimo że pozostały w nim najistotniejsze pytania wyznaczające ową przynależność, wątpliwości przeciw takiej praktyce wydają się uzasadnione. Argumenty przeciw niej są przynajmniej dwa. Po pierwsze, jak przy każdym tego typu narzędziu, także w przypadku pytań faktualnych może zachodzić efekt torowania. Istnieją badania dowodzące wpływu różnych czynników psychologicznych na rzetelność odpowiedzi na tego typu pytania (na przykład Davis i inni 2010). Po drugie, Seyedsayamdost w swoim tekście nie określa, które dokładnie pytania zostały z kwestionariusza usunięte. Podaje jedynie kilka przykładów.

Kontrowersje wzbudza także dobór osób badanych. Można mieć wątpliwość, na ile azjatyccy imigranci i ich potomkowie w Wielkiej Brytanii są tożsamą grupą z imigrantami azjatyckimi i ich potomkami w Stanach Zjednoczonych. Dodatkowo, badanymi byli studenci z wydziałów filozoficznych. Badania zespołu Weinberga przeprowadzono ponad dziesięć lat wcześniej i przez ten czas stały się bardzo popularne (na co wskazuje chociażby przywołana wysoka liczba cytowań). Kwestionariusz przedstawiony studentom zawierał jedynie jedną historyjkę wraz z pytaniem o stan epistemiczny jej bohatera oraz zestaw pytań z kwestionariusza Nisbetta, które wprost dotyczyły kwestii pochodzenia. Co więcej, przykłady gettierowskie i ich znaczenie w dyskusji na temat pojęcia wiedzy omawiane są na wielu podstawowych kursach filozoficznych, ze względu na swoje fundamentalne znaczenie dla współczesnej epistemologii. Istnieje więc wiele powodów, dla których studenci, zwłaszcza z wydziałów filozoficznych, mogli domyślić się, czego dotyczy badanie, co znacząco mogło wpłynąć na ich odpowiedzi.

\section{Drugie badanie Seyedsayamdosta}

Drugie badanie Seyedsayamdost przeprowadził w działajaccym przy LSE laboratorium Behavioural Research Lab. Oferuje ono studentom i pracownikom LSE odpłatne uczestnictwo w badaniach, na które zapraszani są wcześniej mailowo. W tym wypadku badani mieli przypisać stan epistemiczny bohaterom dwóch historyjek (historyjki pochodziły z badania zespołu Weinberga, nie było wśród nich przykładu JiS). Do podziału na grupy użyto tego samego narzędzia, co w pierwszym badaniu, jednak w tym wypadku około połowa osób nie wypełniła go w całości. Fakt ten podważa rzetelność takiego podziału na grupy. Badanych podzielono na sześćdziesięciu czterech Amerykanów i Europejczyków, sześćdziesięciu jeden Azjatów Wschodnich 
oraz sześćdziesięciu Hindusów, co należy uznać za znaczną poprawę w kwestii liczebności grup.

W przypadku drugiego badania, w którym kwestionariusz przyporządkowujący do poszczególnych grup etnicznych był jeszcze bardziej zubożony względem oryginalnego kwestionariusza Nisbetta, powstają te same problemy, na które zwracałem już uwagę przy badaniu pierwszym.

\section{Trzecie badanie Seyedsayamdosta}

Badanie trzecie przeprowadzone zostało online. Na ogólnodostępnym serwerze SurveyMonkey zamieszczono badanie, w którym uczestnicy najpierw zapoznawali się z sześcioma historyjkami, a następnie mieli zadecydować, czy ich bohater coś wie, czy jedynie jest o tym przekonany. Po udzieleniu odpowiedzi wypełniali kwestionariusz demograficzny, w którym pytani byli o rodzimy język i samoidentyfikację etniczną. Grupa badawcza została wstępnie automatycznie zawężona przez sam serwer, który zbiera dane demograficzne na temat swoich użytkowników i skierował prośbę o udział w badaniu jedynie do tych, których sam określił jako Amerykanów i Europejczyków lub Azjatów Wschodnich (ze względu na zbyt małą liczbę Hindusów — dwanaście osób - ich wyniki nie były analizowane). Stanowi to znaczne odstępstwo od metody, którą posługiwał się Weinberg i może zostać uznane za zarzut przeciw badaniom Seyesayadmosta ze względu na nietransparentność kryteriów, jakimi kierował się SurveyMonkey oraz mocne zawężenie pytań, które decydowały o takiej, a nie innej przynależności etnicznej. Grupa badawcza składała się ostatecznie z siedemdziesięciu pięciu Amerykanów i Europejczyków oraz trzydziestu sześciu Azjatów Wschodnich.

\section{Czwarte Badanie Seyedsayamdosta}

Również badanie czwarte przeprowadzane zostało przez internet. Użyto do niego ogólnodostępnej strony projektu Wydziału Psychologii Uniwersytetu Harvarda Moral Sense Test. Wśród wielu innych zadań niezwiązanych z intuicjami epistemicznymi zostało umieszczone pytanie dotyczące historyjki JiS, a także pytanie o język rodzimy i samoidentyfikację etniczną. Pytanie o stan epistemiczny i historyjka zaprezentowane były tak jak w oryginalnym badaniu Weinberga, Nicholsa i Sticha z tą różnicą, że Seyedsayamdost w swoim badaniu zmienił nazwy samochodów z amerykańskich Buick oraz Pontiack na japońskie Honda i Toyota. Przebadanych zostało stu dziewięćdziesięciu trzech Amerykanów i Europejczyków oraz piętnastu Hindusów. Zarzuty do tego badania można podać podobne jak do badania trzeciego ze względu na podział na grupy etniczne. Oprócz tego warto zauważyć, że sama procedura jest odmienna od oryginalnej. Badania bowiem były przeprowadzone online, a nie osobiście, jak w przypadku eksperymentów Weinberga i jego zespołu. Metoda online uniemożliwia stworzenie takich samych lub nawet podobnych warunków badania. Dodatkowo, znów można zwrócić uwagę na ewentualny efekt torowania — jak wspomniałem, pytanie dotyczące historyjki JiS zamieszczone było między innymi zadaniami, których w oryginalnym badaniu nie było.

Jedynie w czwartym badaniu zaobserwowano istotne różnice w odpowiedziach Amerykanów i Europejczyków oraz Hindusów. Jednak autorzy słusznie wskazują na 
niewielką liczbę tych drugich (piętnaście osób), co pozwala wątpić w rzetelność uzyskanego wyniku. Wszelkie inne porównania nie wykazywały żadnych różnic. Wyniki dla przykładu JiS przedstawiam na wykresie 3. Niemniej, jak pokazałem, także w wypadku badań Seyedsayamdosta można wskazać na wiele kontrowersji związanych przede wszystkim z doborem grupy oraz odchyleń w procedurze, które odróżniają ją od procedury w badaniach pierwotnych, co stawia pod znakiem zapytania jakość tych badań zważywszy na ich cel, jakim było powtórzenie badań zespołu Weinberga.

\subsection{Trzecie powtórzenie: Badanie Kim i Yuan}

Ostatnią próbę powtórzenia badania Weinberga, Nicholsa i Sticha podjęły Minsun Kim oraz Yuan Yuan ${ }^{46}$. Przebadały dwustu siedmiu studentów uniwersytetu w Yale, z których dwustu dwóch wypełniło kwestionariusze do końca. Respondenci, tak jak w przypadku oryginalnego badania, pochodzili z północno-wschodniej części Stanów Zjednoczonych.

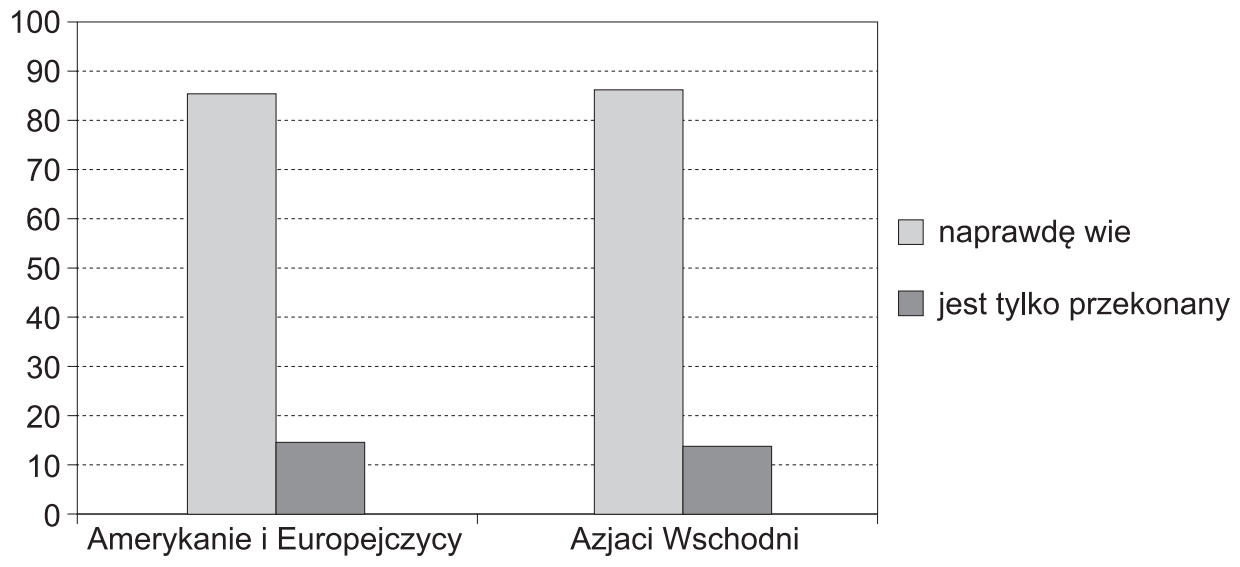

Wykres 3. Wyniki badania Kim i Yuan dla przykładu JiS

Źródło: opracowanie własne.

\section{Procedura i dobór próby}

W pierwszej części badani zapoznawali się z historyjką JiS oraz odpowiadali na pytanie dotyczące stanu epistemicznego jej bohatera. Zarówno historyjka, pytanie, jak i odpowiedzi były identyczne z tymi z oryginalnych badań Weinberga, Nicholsa i Sticha. Dodatkowo badani byli proszeni o zaznaczenie na siedmiostopniowej skali Likerta, na ile są pewni swojej odpowiedzi.

Następnie respondenci wypełniali kwestionariusz demograficzny. Odpowiadali na pytania dotyczące roku studiów i kierunku, płci, pierwszego języka oraz liczby przebytych kursów filozoficznych. Proszeni byli także o zidentyfikowanie się z jakąś grupą etniczną. Ponownie tego typu rozwiązanie bierze pod uwage mniej czynników przy podziale na grupy, niż miało to miejsce w badaniach Weinberga,

${ }^{46}$ M. Kim, Y. Yuan, No cross-cultural..., s. 359-361. 
Nicholsa i Sticha, którzy posługiwali się dłuższym kwestionariuszem Nisbetta. Kim i Yuan uzyskały w ten sposób grupy Amerykanów i Europejczyków oraz Azjatów Wschodnich liczące odpowiednio pięćdziesiąt osiem i osiemdziesiąt dwie osoby. Warto także zwrócić uwagę na fakt, że mimo zbierania informacji na temat przebytych kursów filozoficznych, Kim i Yuan nie skorzystały z tego, aby uwzględnić tę zmienną przy doborze próby — studenci zaś w badaniu Weinberga, Nicholsa i Sticha pochodzili w dużej mierze właśnie z wydziałów humanistycznych. Jest to problem z dwóch powodów. Po pierwsze, nie ma informacji, na ile grupa Kim i Yuan jest podobna pod względem kompetencji filozoficznych do grupy badawczej Weinberga i jego zespołu. Jak wskazywałem, studenci kierunków humanistycznych i filozofii to grupa bardzo szczególna, zwłaszcza w przypadku imigrantów azjatyckich w Stanach Zjednoczonych. Po drugie, tego typu kompetencje pełnią istotną rolę dla wielu teoretyków intuicji epistemicznych, którzy argumentują za tym, że filozofowie mają nie tylko różne, lecz także lepsze intuicje niż nie-filozofowie ${ }^{47}$. Na dużą rolę filozoficznych kompetencji w kształtowaniu intuicji epistemicznych wskazuja także sami filozofowie eksperymentalni ${ }^{48}$. Nawet sami Weinberg, Nichols i Stich wspominają w Normativity and Epistemic Intuitions o istotnych różnicach w intuicjach epistemicznych laików filozoficznych oraz osób z kilkuletnią stycznością z filozofią ${ }^{49}$, co tym bardziej powinno skłonić badaczy chcących podjąć się próby powtórzenia ich badania do kontroli tej zmiennej.

\section{Analiza wyników}

Kim i Yuan nie odnotowały różnic istotnych statystycznie $(\chi 2,(1, \mathrm{~N}=140)=0,02$, $\mathrm{p}=0,89)$ - 85,4\% Azjatów Wschodnich i 86,2\% Amerykanów i Europejczyków odpowiedziało, że bohater jest jedynie przekonany. Dodatkowo autorki przypisywały wagi odpowiedziom (-1 dla ,jest jedynie przekonany" oraz 1 dla ,naprawdę wie”) i przemnożyły przez nie wartość, którą badani podali na siedmiostopniowej skali Likerta, oceniając swoją pewność co do odpowiedzi. W ten sposób mogły wyliczyć siłę przypisania lub odmówienia wiedzy bohaterowi z historyjki, gdzie wynik -7 oznaczał „W całkowitą pewność przy odmówieniu wiedzy bohaterowi”, a 7 - „w całkowitac pewność przy przypisaniu wiedzy". Po przyjęciu przedziału ufności na nominalnym poziomie 95\% cały przedział dla Amerykanów i Europejczyków mieścił się między -4,53 a -2,73, dla Azjatów Wschodnich natomiast między -4,63 a -2,58. Kim i Yuan uznały to za dowód, że obie grupy w sposób niezachwiany przypisały bohaterowi historyjki jedynie przekonanie. Ostatni wniosek wydaje się jednak arbitralny. Trudno w ogóle znaleźć argumenty za przyjęciem tezy o „niezachwianym” przypisaniu ,,jedynie przekonania" na podstawie wyniku między $-4,63$ a $-2,58$ zważywszy na to, jakie wartości skrajne posiadała skala w badaniu. Autorki także nie podają żadnych argumentów, a jedynie formułują wniosek. Wyniki Kim i Yuan prezentuję na wykresie 4.

Także w przypadku tego badania można wskazać na pewne uchybienia metodologiczne. Wydaje się jednak, że spośród innych badanie Kim i Yuan jest prze-

47 Por. K. Ludwig, The Epistemology..., s. 128-159; A. Kauppinen, The rise..., s. 95-118.

${ }^{48}$ M.in. W. Buckwalter, S. Stich, Gender and philosophical intuition, [w:] Experimental Philosophy: Volume 2, J. Knobe, S. Nichols (eds.), Oxford 2013, s. 307-346.

49 Zob. J.M. Weinberg, S. Nichols, S. Stich, Normativity..., s. 452. 
prowadzone najrzetelniej, zważywszy, że ich celem było powtórzenie wyników Weinberga, Nicholsa i Sticha przy zastosowaniu możliwie podobnej metodologii do oryginalnej.

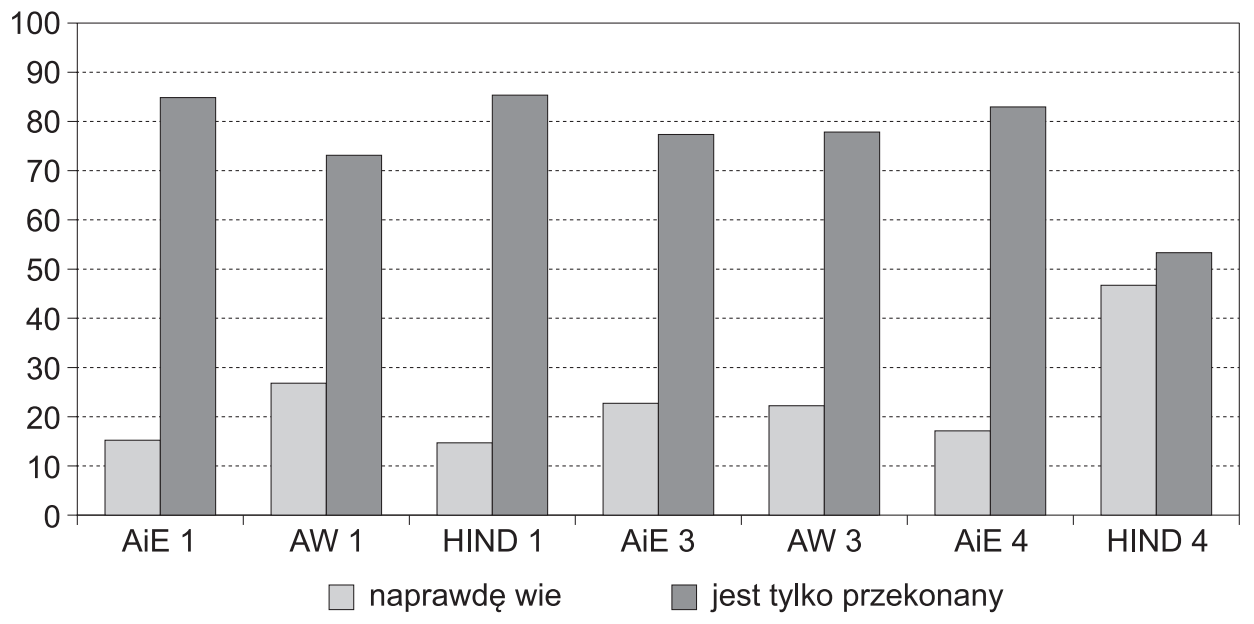

Wykres 4. Wyniki badań Seyedsayamdosta dla przykładu JiS. Legenda: AiE - Amerykanie i Europejczycy, AW - Azjaci Wschodni, HIND - Hindusi (obok skrótu mniejszości kulturowej cyfra odpowiadająca numerowi badania)

Źródło: opracowanie własne.

\section{Czego (nie) dowodzą próby powtórzenia badania Weinberga, Nicholsa i Sticha - wnioski}

Należy zwrócić uwagę na dwie kwestie. Po pierwsze, na ile wskazane błędy metodologiczne omówionych badań wpływają na decyzję o uznaniu nieudanych prób powtórzenia badania Weinberga, Nicholsa i Sticha jako argumentów przeciw stabilności efektu, który został w nim zaobserwowany. Po drugie, na ile wspomniane badania (wszystkie, łącznie z oryginalnym) są trafne treściowo, to znaczy, co mówią nam na temat rzeczywistych międzykulturowych różnic intuicji epistemicznych.

Pierwszy problem dotyczy w gruncie rzeczy tego, czy na podstawie nieudanych prób powtórzenia oryginalnego badania można uznać — przyjmując operacjonalizację zmiennych zaproponowaną przez Weinberga, Nicholsa i Sticha — że intuicje epistemiczne nie są zróżnicowane międzykulturowo. Sądzę, że w tym wypadku odpowiedź powinna być pozytywna. Oceniając nawet najbardziej surowo wspomniane badania, należy przyznać, że większość zarzutów metodologicznych, które są im stawiane albo były popełnione także przez zespół Weinberga (jak w przypadku zbyt małej liczebności grup badanych), albo odnoszą się w gruncie rzeczy do trafności treściowej, dotyczą więc tego, na ile operacjonalizacja zaproponowana przez Weinberga, Nicholsa i Sticha rzeczywiście odpowiada badanym zjawiskom. Warto w tym miejscu nadmienić, że pewnym błędem, o którym jeszcze nie wspominałem, a został popeł- 
niony przez wszystkich omawianych badaczy, był dobór grup. W każdym z badań grupy były dobierane oportunistycznie — były więc mało zróżnicowane, przypadkowe i specyficzne; trudno je jednak uważać za reprezentatywne dla populacji. W tym jednak wypadku błąd ten popełniony został również przez Weinberga. W przypadku badania Kim i Yuan można uznać, że ich grupa badawcza właśnie dzięki doborowi oportunistycznemu była zbliżona do tej z oryginalnego badania.

Przedstawione dotychczas analizy nie podważają negatywnych wyników uzyskanych w badaniach, których celem było powtórzenie wyników zespołu Weinberga. Wskazują raczej, jak nieprzemyślane pod względem metodologicznym bywają często badania filozofii eksperymentalnej, a także, jak trudne jest przeprowadzenie naprawdę rzetelnego powtórzenia badań. Przytoczone przeze mnie przykłady pomagają także wywnioskować, jakie wymagania należy stawiać badaniom filozofii eksperymentalnej. Konieczne są większe grupy badawcze, lepsza kontrola innych zmiennych, takich jak wiek, płeć czy kompetencja filozoficzna (zwłaszcza przy doniesieniach o ich wpływie na intuicje epistemiczne). Częstym problemem tekstów opisujących tego typu badania jest ich nietransparentność. Niejawne kwestionariusze używane do podziału na grupy czy przemilczana kolejność prezentacji scenariuszy to błędy, które drastycznie obniżają wartość wielu badań z tego obszaru.

Uczciwie należy przy tym zauważyć, że świadomość metodologiczna wśród filozofów eksperymentalnych rośnie i coraz częściej można spotkać badania o dużym stopniu transparentności, reprezentatywnych próbach i kontrolowanych zmiennych. Można przywołać w tym miejscu nazwiska chociażby Johna Turri'ego, Aarona Meskina czy w Polsce na przykład Katarzyny Kuś, którzy dbają o poprawność metodologiczną w konstruowaniu badań, a także zamieszczają w swoich publikacjach obszerne materiały wykorzystane w eksperymentach. Nie jest to jednak, niestety, zasada. Co prawda badanie Weinberga, Nicholsa i Sticha jest założycielskie dla filozofii eksperymentalnej i zostało przeprowadzone ponad piętnaście lat temu, jednak chociażby w omawianych badaniach, których celem było powtórzenie wyników Weinberga, Nicholsa i Sticha, wciąż popełniano błędy, mimo że zostały one przeprowadzone dużo później — w latach 2013-2015.

Warto to podkreślić raz jeszcze: wytknięte błędy w badaniach Nagel, San Juan i Mar, Seyedsayamdosta oraz Kim i Yuannie nie podważają ostatecznego wniosku — nie udaje się uzyskać wyników takich jak te, które uzyskał zespół Weinberga. Nie ma podstaw, by mówić o drastycznych różnicach międzykulturowych w intuicjach epistemicznych (przy takiej operacjonalizacji, jaką zaproponowali Weinberg, Nichols i Stich). Tezę tę wzmacniają wyniki innych badań dotyczących międzykulturowego zróżnicowania intuicji epistemicznych, w których używano innych metod lub przykładów ${ }^{50}$. Aby uprzedzić ewentualne przedwczesne wnioski — wysnuwane między innymi przez Kim i Yuan ${ }^{51}$ — na temat uniwersalności intuicji epistemicznych, należy przywołać tu także inne badania, które wskazują na istnienie różnic ze względu

${ }^{50}$ Por. M. Kim, Y. Yuan, Cross-Cultural...; E. Machery et al., Gettier across cultures, „Noûs” 50 [2] (2015), s. 1-20; J. Turri, A conspicuous art: Putting Gettier to the test, „Philosophers' Imprint” 13 [10] (2013), s. 1-16.

51 Por. M. Kim, Y. Yuan, No Cross-Cultural..., s. 258-361; M. Kim, Y. Yuan, Cross-Cultural..., passim. 
na inne czynniki demograficzne, na przykład wiek ${ }^{52}$ czy płeć ${ }^{53}$. Jednak problemy związane z trafnością treściową mogą budzić poważne zastrzeżenia czy wspomniany wynik mówi cokolwiek na temat braku rzeczywistych różnic intuicji epistemicznych między kulturami. Jest tak przynajmniej przy takim rozumieniu, w jakim intuicje chcą rozumieć filozofowie, a więc takich intuicji, z których korzysta się w argumentacji filozoficznej.

\section{APENDYKS}

Dla większej przejrzystości zamieszczam wyniki liczbowe dla omawianych przykładów eksperymentów. Wyniki istotne statystycznie, a więc przy p $<0.05$ oznaczać będę gwiazdką $(*)$.

Badanie Weinberga, Nicholsa i Sticha ${ }^{54}$, przykład JiS:

\begin{tabular}{|c|c|c|}
\hline & Really knows & Only believes \\
\hline $\begin{array}{c}\text { Amerykanie } \\
\text { i Europejczycy }\end{array}$ & 17 & 49 \\
\hline Azjaci Wschodni & 13 & 10 \\
\hline Hindusi & 14 & 9 \\
\hline
\end{tabular}

Analiza testem Fishera, Amerykanie i Europejczycy/Azjaci Wschodni $\mathrm{p}=0.006414^{*}$; Amerykanie i Europejczycy/Hindusi $\mathrm{p}=0.002407^{*}$

Badanie Nagel, San Juan, Mar55, przykład JiS:

\begin{tabular}{|c|c|c|c|}
\hline & $\begin{array}{c}\text { Immediate } \\
\text { knowledge denial }\end{array}$ & $\begin{array}{c}\text { Delayed } \\
\text { knowledge denial }\end{array}$ & $\begin{array}{c}\text { Unwavering } \\
\text { knowledge ascription }\end{array}$ \\
\hline $\begin{array}{c}\text { Amerykanie } \\
\text { i Europejczycy }\end{array}$ & 27 & 16 & 20 \\
\hline Azjaci Wschodni & 10 & 5 & 6 \\
\hline Hindusi & 17 & 7 & 18 \\
\hline
\end{tabular}

Jednoczynnikowa analiza wariancji ANOVA, Amerykanie i Europejczycy/Azjaci Wschodni $\mathrm{p}=0.669163$; Amerykanie i Europejczycy/Hindusi $\mathrm{p}=0.498274$

52 Por. D. Colaço et al., Epistemic intuitions in fake-barn thought experiments, „Episteme” 11 [2] (2014), s. 199-212.

${ }^{53}$ Por. W. Buckwalter, S. Stich, Gender..., passim.

54 J.M. Weinberg, S. Nichols, S. Stich, Normativity..., s. 429-460.

55 J. Nagel, V. San Juan, R.A. Mar, Lay denial..., s. 652-661. 
Pierwsze badanie Seyedsayamdosta ${ }^{56}$, przykład JiS:

\begin{tabular}{|c|c|c|}
\hline & Really knows & Only believes \\
\hline $\begin{array}{c}\text { Amerykanie } \\
\text { i Europejczycy }\end{array}$ & 12 & 67 \\
\hline Azjaci Wschodni & 11 & 30 \\
\hline Hindusi & 5 & 29 \\
\hline
\end{tabular}

Brak informacji na temat wyboru testu, Amerykanie i Europejczycy/ Azjaci Wschodni $\mathrm{p}=0.146$; Amerykanie i Europejczycy/Hindusi $\mathrm{p}=1$

Trzecie badanie Seyedsayamdosta ${ }^{57}$, przykład JiS:

\begin{tabular}{|c|c|c|}
\hline & Really knows & Only believes \\
\hline $\begin{array}{c}\text { Amerykanie } \\
\text { i Europejczycy }\end{array}$ & 17 & 58 \\
\hline Azjaci Wschodni & 8 & 28 \\
\hline
\end{tabular}

Brak informacji na temat wyboru testu, $\mathrm{p}=1$

Czwarte badanie Seyedsayamdosta ${ }^{58}$, przykład JiS:

\begin{tabular}{|c|c|c|}
\hline & Really knows & Only believes \\
\hline $\begin{array}{c}\text { Amerykanie } \\
\text { i Europejczycy }\end{array}$ & 35 & 158 \\
\hline Hindusi & 7 & 8 \\
\hline
\end{tabular}

Brak informacji na temat wyboru testu, $\mathrm{p}=0.011^{*}$

Badanie Kim i Yuan ${ }^{59}$, przykład JiS:

\begin{tabular}{|c|c|c|}
\hline & Really knows & Only believes \\
\hline $\begin{array}{c}\text { Amerykanie } \\
\text { i Europejczycy }\end{array}$ & 8 & 50 \\
\hline Azjaci Wschodni & 12 & 70 \\
\hline
\end{tabular}

Analiza testem zgodności chi-kwadrat, $\mathrm{p}=0.89$

\footnotetext{
${ }^{56}$ H. Seyedsayamdost, On normativity..., s. 95-116.

57 Ibidem.

58 Ibidem.

${ }^{59}$ M. Kim, Y. Yuan, No cross-cultural..., s. 355-361.
} 


\section{Bibliografia}

Andow J., Thin, fine and with sensitivity: a metamethodology of intuitions, „Review of Philosophy and Psychology" 7 [1] (2016), s. 105-125.

Alexander J., Experimental Philosophy. An Introduction, Cambridge 2012.

Buckwalter W., Stich S., Gender and philosophical intuition, [w:] Experimental Philosophy: Volume 2, Knobe J., Nichols S. (eds.), Oxford 2013.

Budzicz Ł., Wartość poznawcza badań empirycznych w psychologii społecznej, niepublikowana rozprawa doktorska, Uniwersytet Adama Mickiewicza w Poznaniu 2015.

Cappelen H., Philosophy without intuitions, Oxford 2012.

Cappelen H., X-Phi without Intuitions, [w:] Intuitions, A. Booth, D. Rowbottom (eds.), Oxford 2014, s. 269-286.

Chalmers D., Intuitions in philosophy: A minimal defense, „Philosophical Studies” 171 [3] (2014), s. 535-544.

Colaço D. et al., Epistemic intuitions in fake-barn thought experiments, „Episteme” 11 [2] (2014), s. 199-212.

Cullen S., Survey-driven romanticism, „Review of Philosophy and Psychology” 1 [2] (2010), s. 275-296.

Davis R.E. et al., Interviewer effects in public health surveys, „Health education rese$\operatorname{arch"} 25$ [1] (2010), s. 14-26.

Deutsch M., Intuitions, counter-examples, and experimental philosophy, „Review of Philosophy and Psychology" 1 [3] (2010), s. 447-460.

Deutsch M., The myth of the intuitive: Experimental philosophy and philosophical method, MIT Press 2015.

Field of Bachelor's Degree in the United States, American Community Survey Reports 2009

Gettier E.L., Is justified true belief knowledge?, „Analysis” 23 [6] (1963), s. 121-123; (przekład polski: Czy uzasadnione i prawdziwe przekonanie jest wiedza?, „Principia” 1 (1990), J. Hartman, J. Robus, s. 93-96).

Greene J., Haidt, J., How (and where) does moral judgment work?, „Trends in Cognitive Science" 6 [12] (2002), s. 517-523.

Haidt J., Koller S.H., Dias M.G., Affect, culture, and morality, or is it wrong to eat your dog?, „Journal of Personality and Social Psychology” 65 [4] (1993), s. 613-628.

Hall L., Johansson P., Strandberg T., Lifting the Veil of Morality: Choice Blindness and Attitude Reversals on a Self-Transforming Survey, „PLoS ONE” 7 [9] (2012), s. $1-8$.

Hüffmeier J., Mazei J., Schultze T., Reconceptualizing replication as a sequence of different studies: A replication typology, „Journal of Experimental Social Psychology” 66 (2016), s. 81-92.

Ioannidis J.P., Why most published research findings are false, „PLoS medicine”, 2 [8] (2005), s. 696-701.

International Student Enrollment Trends, 1948/49-2014/15 (2015), Open Doors Report on International Educational Exchange, https://www.iie.org/Research-and-Insights/Open-Doors/Data/International-Students/Enrollment-Trends.

Kauppinen A., The rise and fall of experimental philosophy, „Philosophical Explorations" 10 [2] (2007), s. 95-118. 
Kim M., Yuan Y., No cross-cultural differences in the Gettier car case intuition: A replication study of Weinberg et al. 2001, „Episteme” 12 [3] (2015), s. 355-361.

Kim M., Yuan Y., Cross-Cultural Universality in Knowledge Attributions, 2016, https://philpapers.org/archive/YUACUO.pdf.

Kerr E.T., Epistemological Experiments and Empirical Philosophy in Cross-Cultural Contexts, „Asia Research Institute Working Paper Series” 233 (2015), s. 1-27.

Knobe J., Experimental philosophy is cognitive science, [w:] A companion to experimental philosophy, J. Sytsma, W Buckwalter (eds.), New York 2016, s. 37-52.

Knobe J., Intentional action in folk psychology: An experimental investigation, „Philosophical Psychology" 16 [2] (2005), s. 309-325.

Knobe J., Nichols S., An Experimental Philosophy Manifesto, [w:] Experimental Philosophy, J. Knobe, S. Nichols (eds.), Oxford 2008, s. 3-14.

Komorowska-Mach J., Negatywny program filozofii eksperymentalnej a odwołania do intuicji w argumentacji filozoficznej, „Filozofia Nauki” 3 [83] (2013), s. 157-165.

Kucharska J., Problemy psychiczne w grupach mniejszości etnicznych $i$ narodowych, „Psychiatria Polska” 46 [3] (2012), s. 451-459.

Ludwig K., The Epistemology of Thought Experiments: First Person versus Third Person Approaches, „Midwest Studies in Philosophy” 31 (2007), s. 128-59.

Machery E. et al., Gettier across cultures, „Noûs” 50 [2] (2015), s. 1-20.

Nadelhoffer T., Nahmias E., The past and future of experimental philosophy, „Philosophical Explorations" 10 [2] (2007), s. 123-149.

Nagel J., San Juan V., Mar R.A., Lay denial of knowledge for justified true beliefs, „Cognition” 129 [3] (2013), s. 652-661.

Nahmias E., Morris S.G., Nadelhoffer T., Turner J., Is Incompatibilism Intuitive?, „Philosophy and Phenomenological Research" 73 [1] (2006), s. 28-53.

Nisbett R.E., Wilson T.D., Telling more than we can know: Verbal reports on mental processes, „Psychological Review” 84 [3] (1977), s. 231-259.

Nisbett R.E. et al., Culture and systems of thought: holistic versus analytic cognition, „Psychological Review” 108 [2] (2001), s. 291-310.

Schmidt S., Shall we really do it again? The powerful concept of replication is neglected in the social sciences, „Review of General Psychology” 13 [2] (2009), s. 90-100.

Schwarz N., Self reports: how the questions shape the answers, „American Psychologist” 54 [2] (1999), s. 93-105.

Seyedsayamdost H., On normativity and epistemic intuitions: Failure of replication, „Episteme” 12 [1] (2015), s. 95-116.

Shackelford E., Smith R.A., Issue Brief: Immigration and Socioeconomic Status, publikacja pokonferencyjna: „Race and Ethnicity in American Politics” 2010.

Turri J., A conspicuous art: Putting Gettier to the test, „Philosophers' Imprint” 13 [10] (2013), s. $1-16$.

Von Hippel W., Trivers R., The evolution and psychology of self-deception, „Behavioral and Brain Sciences" 34 [1] (2011), s. 1-16.

Weinberg J.M., Nichols S., Stich S., Normativity and epistemic intuitions, „Philosophical Topics" 29 [1-2] (2001), s. 429-460.

Williamson T., Philosophy vs. Imitation Psychology, The New York Times 2010, https://www.nytimes.com/roomfordebate/2010/08/19/x-phis-new-take-on-old-problems/philosophy-vs-imitation-psychology. 
Williamson T., Philosophical Criticisms of Experimental Philosophy, [w:] A Companion to Experimental Philosophy, J. Sytsma, W. Buckwalter (eds.), New York 2016.

Woolfolk R.L., Experimental Philosophy: A Methodological Critique, „Metaphilosophy” 44 [1-2] (2013), s. 79-87.

Wysocki T., Filozofia eksperymentalna jako metodologia filozoficzna, publikacja internetowa 2011, http://www.xphi-europe.org/filozofiaeksperymentalna.pdf. 